\title{
Improvement of mRNA Delivery Efficiency to a T Cell Line by Modulating PEG-Lipid Content and Phospholipid Components of Lipid Nanoparticles
}

\author{
Hiroki Tanaka ${ }^{1, *} \mathbb{D}$, Ryo Miyama ${ }^{1}$, Yu Sakurai ${ }^{1}\left(\mathbb{D}\right.$, Shinya Tamagawa ${ }^{2}$, Yuta Nakai ${ }^{2}$, Kota Tange ${ }^{2}$, \\ Hiroki Yoshioka ${ }^{2}$ and Hidetaka Akita ${ }^{1, *}$ \\ 1 Laboratory of DDS Design and Drug Disposition, Graduate School of Pharmaceutical Sciences, \\ Chiba University, 1-8-1 Inohana, Chuo-ku, Chiba City 260-0856, Japan; bfdref@gmail.com (R.M.); \\ yu_sakurai@chiba-u.jp (Y.S.) \\ 2 DDS Research Laboratory, NOF CORPORATION, 3-3 Chidori-cho, Kawasaki-ku, \\ Kawasaki City 210-0865, Japan; shinya_tamagawa@nof.co.jp (S.T.); yuta_nakai@nof.co.jp (Y.N.); \\ kota_tange@nof.co.jp (K.T.); hiroki_yoshioka@nof.co.jp (H.Y.) \\ * Correspondence: hiroki_tanaka8922@chiba-u.jp (H.T.); akitahide@chiba-u.jp (H.A.); \\ Tel.: +81-43-226-2894 (H.T.); +81-43-226-2893 (H.A.)
}

Citation: Tanaka, H.; Miyama, R.; Sakurai, Y.; Tamagawa, S.; Nakai, Y.; Tange, K.; Yoshioka, H.; Akita, H. Improvement of mRNA Delivery Efficiency to a T Cell Line by Modulating PEG-Lipid Content and Phospholipid Components of Lipid Nanoparticles. Pharmaceutics 2021, 13, 2097. https://doi.org/10.3390/ pharmaceutics13122097

Academic Editors: Shintaro Fumoto and Tsuyoshi Yamamoto

Received: 27 October 2021

Accepted: 2 December 2021

Published: 6 December 2021

Publisher's Note: MDPI stays neutra with regard to jurisdictional claims in published maps and institutional affiliations.

Copyright: (c) 2021 by the authors. Licensee MDPI, Basel, Switzerland. This article is an open access article distributed under the terms and conditions of the Creative Commons Attribution (CC BY) license (https:// creativecommons.org/licenses/by/ $4.0 /)$.

\begin{abstract}
Background: T cells are important target cells, since they exert direct cytotoxic effects on infected/malignant cells, and affect the regulatory functions of other immune cells in a target antigen-specific manner. One of the current approaches for modifying the function of $\mathrm{T}$ cells is gene transfection by viral vectors. However, the insertion of the exogenous DNA molecules into the genome is attended by the risk of mutagenesis, especially when a transposon-based gene cassette is used. Based on this scenario, the transient expression of proteins by an in vitro-transcribed messenger RNA (IVT-mRNA) has become a subject of interest. The use of lipid nanoparticles (LNPs) for the transfection of IVT-mRNA is one of the more promising strategies for introducing exogenous genes. In this study, we report on the development of LNPs with transfection efficiencies that are comparable to that for electroporation in a T cell line (Jurkat cells). (2) Methods: Transfection efficiency was improved by optimizing the phospholipids and polyethylene glycol (PEG)-conjugated lipid components. (3) Results: Modification of the lipid composition resulted in the 221-fold increase in luciferase activity compared to a previously optimized formulation. Such a high transfection activity was due to the efficient uptake by clathrin/dynamin-dependent endocytosis and the relatively efficient escape into the cytoplasm at an early stage of endocytosis.
\end{abstract}

Keywords: mRNA delivery; lipid nanoparticles; T cells

\section{Introduction}

Manipulation of the functions of immune cells by gene delivery is one of the more promising strategies in the field of medical science. Among the immune cells, $\mathrm{T}$ cells are important target cells since they can exert direct cytotoxic effects on infected/malignant cells, and play a role in the regulatory functions of other immune cells in a target antigen specific manner [1]. An ex vivo T cell therapy was recently developed based on the cell-killing activity of CD8+ T cells [2]. A typical example of such ex vivo T cell therapy is chimeric antigen receptor (CAR) introduced T cell (CAR-T) therapy [3]. The CAR is an artificial chimeric protein that is composed of a target recognition domain (single-chain variable fragment of an antibody) and intracellular T cell activating domains. The target of the CAR-T cells can be controlled by modifying the sequence of the target recognition domain. While early applications of such CAR-T cells were limited to B cell leukemia by targeting the CD19 protein on the tumor cells [4], applications are now being expanded to solid tumors or to other purposes such as the eradication of senescent cells from the body 
(senolysis) [5,6]. In addition to the CAR protein, other proteins have been widely investigated for further functional modifications of $\mathrm{T}$ cells. Representatives of such modifications include an enhancement in cytotoxic activity by avoiding $\mathrm{T}$ cell exhaustion [7], improved safety profiles by removing inherent $\mathrm{T}$ cell receptors from the $\mathrm{T}$ cell population [8], and the establishment of universal CAR-T cells by eliminating major histocompatibility complexes from their genome [8]. For these purposes, a highly efficient and safe technology for introducing exogenous proteins to the T cells is urgently needed.

Current approaches for the introduction of these exogenous genes to $\mathrm{T}$ cells have largely involved the use of viral vectors [9]. While these vectors can achieve efficient gene expression, the risk of the insertion of exogenous DNAs into the genome is always a possibility [10-12]. Moreover, the permanent alteration of the genome is attended by the additional risk of persistent adverse events [13]. As a solution to these problems, the transient expression of proteins by an in vitro-transcribed messenger RNA (IVT-mRNA) has attracted the interest of scientists in this field. Since IVT-mRNA is a highly vulnerable and hydrophilic molecule, its introduction into the T cells requires a delivery system.

One of the currently available methods for the transfection of the IVT-mRNA is electroporation [14]. Electroporation causes the perturbation of the plasma membrane using electric pulses. The IVT-mRNA can then be internalized into the cytoplasm through the pores generated by this perturbation. Electroporation allows the efficient and uniform introduction of the IVT-mRNA independent of endocytosis. On the other hand, electroporation could cause integrated stress responses and $\mathrm{T}$ cell exhaustion, probably triggered by the perturbation of the plasma membrane [15]. Transfection using lipid nanoparticles (LNPs) is an alternative strategy for introducing IVT-mRNA into cells. LNPs typically contain an artificial amphiphilic material referred as to a $\mathrm{pH}$-sensitive cationic lipid or an ionizable lipid [16-21]. The head groups of ionizable lipids contain tertiary amine moieties and a backbone composed of hydrophobic scaffolds. Once taken up by the cells, the tertiary amine moiety can sense the lower $\mathrm{pH}$ of the endosomal compartment and then promote the cytoplasmic delivery of the genes and/or oligonucleotides. In 2018, Onpattro ${ }^{\circledR}$, an siRNA formulated in an LNP, was approved as the first siRNA therapeutics [22]. More recently, RNA vaccine technologies against SARS-CoV-2 have been approved [23-25]. These historic successes of the therapeutic applications of the LNPs promise to accelerate further applications of the LNPs in the biological and medical field.

Regarding the delivery of nucleic acids, it is generally considered that $\mathrm{T}$ cells are negligibly transfected in comparison with other possible targets; both immune cells (macrophages or dendritic cells) and non-immune cells (hepatocytes or tumor cells) [26,27]. One plausible reason for this difference is that the activity of endocytosis of the T cells is poor $[28,29]$. To achieve successful transfection to the T cells, the development of an LNP that can be taken up by the T cells is prerequisite. The interaction between the LNPs and the cells is affected by the surface properties of the LNPs. Therefore, lipid components, especially those with hydrophilic moieties, would be expected to significantly affect transfection efficiency. In this study, we report on the development of LNPs that show a transfection efficiency comparable to that for electroporation in a T cell line (Jurkat cells) without cellular stress responses and toxicity. In this process, the type of phospholipids, and their composition, in parallel with polyethylene glycol (PEG)-conjugated lipids was optimized.

\section{Materials and Methods}

\subsection{Materials}

Detailed supplier's information including item numbers of all reagents used in this study are listed in Supplementary Materials (Table S1). As a component of LNPs, a selfdegradable lipid-like material was used (ssPalmO-Phe-P4C2) [30]. The ssPalmO-Phe-P4C2 (Product\# COATSOME ${ }^{\circledR}$ SS-OP), 1,2-dioleoyl-sn-glycero-3-phosphatidylcholine (DOPC, Product\# COATSOME ${ }^{\circledR}$ MC-8181), 1-palmitoyl-2-oleoyl-sn-glycero-3-phosphatidylcholine (POPC, Product \# COATSOME ${ }^{\circledR}$ MC-6081), 1-palmitoyl-2-oleoyl-sn-glycero-3phosphatidylethanolamine (POPE, Product \# COATSOME ${ }^{\circledR}$ ME-6081), and 1-(Monomethoxy 
polyethyleneglycol2000)2,3-dimyristoylglycerol (DMG-PEG2000, Product \# SUNBRIGHT ${ }^{\circledR}$ GM-020) were supplied by NOF CORPORATION (Tokyo, Japan). The information of the stock solution of lipids is summarized in the supporting materials (Table S2). The IVT-mRNAs coding reporter genes (firefly luciferase and EGFP) were purchased from TriLink BioTechnologies (San Diego, CA, USA). Quant-IT ${ }^{\text {TM }}$ RiboGreen ${ }^{\circledR}$ RNA reagent and Lipofectamine ${ }^{\circledR}$ MessengerMAX were purchased from ThermoFisher Scientific (Waltham, MA, USA). Pitstop ${ }^{\circledR} 2$ Novel cell-permeable clathrin inhibitor and Dynole ${ }^{\circledR} 34-2$ dynamin I and dynamin II inhibitor were purchased from Abcam plc (Cambridge, UK). InSolution $^{\mathrm{TM}}$ Cytochalasin D and cholesterol was purchased from Sigma-Aldrich (St. Louis, MO, USA). Genistein was purchased from Santa Cruz Biotechnology (Dallas, TX, USA). All other reagents and chemicals were commercially available and were used without further purification.

\subsection{Cell Culture}

Jurkat cells were cultured using RPMI 1640 medium supplemented with 10\% (v/v) FBS, $1 \mathrm{mM}$ sodium pyruvate, $10 \mathrm{mM}$ HEPES, $100 \mathrm{U} / \mathrm{mL}$ of penicillin, $4.5 \mathrm{~g} / \mathrm{L}$ glucose and $100 \mathrm{mg} / \mathrm{mL}$ of streptomycin. Cells were cultured in $10 \mathrm{~cm}$ dishes (Asnol Sterilization Petri Dish $\varphi 90 \times 15 \mathrm{~mm}$, AS ONE Corporation, Osaka, Japan) and were passed when they reached $80 \%$ confluence. Typical passage timing was at 3-day intervals. The cells were cultured under an atmosphere of $5 \% \mathrm{CO}_{2} /$ air at $37^{\circ} \mathrm{C}$.

\subsection{Preparation of the $m R N A-L N P$}

The IVT-mRNA encoding luciferase or EGFP was diluted with a $20 \mathrm{mM}$ malic acid buffer ( $30 \mathrm{mM} \mathrm{NaCl}, \mathrm{pH} 3.0)$ at a concentration of $0.0067 \mu \mathrm{g} / \mu \mathrm{L}$. The lipid ethanol solution was prepared at a concentration of $4 \mathrm{mM}$. The detailed description for the preparation of the lipid mixtures is summarized in the supporting materials (Table S3). These solutions were mixed using a microfluidics device (NanoAssemblr ${ }^{\mathrm{TM}}$, Precision NanoSystems, Vancouver, $\mathrm{BC}$, Canada) (total flow rate; $4 \mathrm{~mL} / \mathrm{min}$, flow ratio; water $/$ ethanol $=3 / 1(v / v)$ ). The mixture of the mRNA and lipids $(0.8 \mathrm{~mL})$ were recovered and diluted with $3 \mathrm{~mL}$ of $\mathrm{MES} / \mathrm{NaOH}$ buffer (2-(N-morpholino) ethanesulfonic acid, $20 \mathrm{mM}$, pH6.5). The external solution was replaced with PBS(-) by ultrafiltration using Amicon Ultra-4-100K centrifugal units. The particle solution was diluted to an adequate concentration with PBS(-) before transfection.

\subsection{Characterization of the Particles}

Size, Polydispersity Index (PdI), and Zeta-potential of LNPs were measured by dynamic light scattering (Zetasizer nano ZS, Malvern Panalytical, Malvern, UK). Encapsulation efficiency of the IVT-mRNA were obtained by Quant-IT ${ }^{\mathrm{TM}}$ RiboGreen $^{\circledR}$ assay [30].

\section{5. mRNA Transfection and In Vitro Luciferase Assay}

\subsubsection{Transfection by Electroporation (EP)}

Jurkat cells were resuspended in Opti-MEM $\left(1.11 \times 10^{7}\right.$ cells $\left./ \mu \mathrm{L}, 90 \mu \mathrm{L}\right)$. An mRNA solution was diluted in Opti-MEM $(0.2 \mu \mathrm{g} / \mu \mathrm{L}, 10 \mu \mathrm{L})$. The mRNA solution was then added to the cell suspension and set to an electroporator NEPA21 Type II (Nepa Gene Co., Ltd., Chiba, Japan). The electroporation was conducted at a Pp (poring pulse) of $175 \mathrm{~V}$; a Pp duration of $2.5 \mathrm{~ms}$; a Pp interval of $50 \mathrm{~ms}$; a Pp frequency of 2 times; a Pp decay rate of $10 \%$; a Tp (Transfer pulse) of $\pm 20 \mathrm{~V}$; a Tp duration of $50 \mathrm{~ms}$; a Tp interval of $50 \mathrm{~ms}$; a Tp frequency of 5 times for \pm Voltage; a Tp decay rate of $40 \%$. Immediately after the electric pulses, the cells were collected by adding $300 \mu \mathrm{L}$ of culture media. The cells were incubated for $1 \mathrm{~h}$ at $37^{\circ} \mathrm{C}$ in the $\mathrm{CO}_{2}$ incubator. After the recovery culture, the cells were collected by centrifugation $\left(4^{\circ} \mathrm{C}, 500 \times g, 3 \mathrm{~min}\right)$, and then resuspended at a concentration of $1 \times 10^{5}$ cells $/ \mathrm{mL}$ in culture media containing serum. The cells were transferred to $3.5 \mathrm{~cm}$ dishes $\left(1 \times 10^{5}\right.$ cells $\left./ \mathrm{mL}, 2 \mathrm{~mL}\right)$. 


\subsubsection{Transfection by Lipofectamine MessengerMAX (LFN)}

The transfection was conducted according to the manufacture's protocol. Jurkat cells $\left(1 \times 10^{5}\right.$ cells $\left./ \mathrm{mL}, 2 \mathrm{~mL}\right)$ were seeded in $3.5 \mathrm{~cm}$ dishes. Lipofectamine MessengerMAX reagent (ThermoFisher Scientific, Waltham, MA, USA) and the mRNA were mixed in the Opti-MEM (ThermoFisher Scientific, Waltham, MA, USA) at a ratio of $1.5 \mu \mathrm{L}$ reagent $/ \mu \mathrm{g}$ mRNA $(0.5 \mu \mathrm{g})$. The mixture was incubated for $5 \mathrm{~min}$. After the incubation, the mixture was transfected to the Jurkat cells in culture media containing serum.

\subsubsection{Transfection by Lipid Nanoparticles (LNPs)}

Jurkat cells $\left(1 \times 10^{5}\right.$ cells $\left./ \mathrm{mL}, 2 \mathrm{~mL}\right)$ were seeded in $3.5 \mathrm{~cm}$ dishes. The LNPs containing $0.4 \mu \mathrm{g}$ of mRNA was added to the Jurkat cells in culture media containing serum.

\subsubsection{Luciferase Assay with Incubator-Type Luminometer}

In all samples (EP, LFN, and LNP), final concentration of the mRNA and the cells were $0.2 \mu \mathrm{g} / \mathrm{mL}$ and $1 \times 10^{5}$ cells $/ \mathrm{mL}$. The cells were incubated in culture media containing $100 \mu \mathrm{M}$ of D-luciferin potassium on the $3.5 \mathrm{~cm}$ dishes. The cells were placed in an incubatortype luminometer (Kronos, ATTO, Tokyo, Japan) and the luciferase activity was measured for $2 \mathrm{~min}$ at $1 \mathrm{~h}$ intervals.

\subsection{Analysis of Phosphorylation of eIF $2 \alpha$}

The IVT-mRNA was transfected to the Jurkat cells by EP or LNPs as described in Section 2.5. At 1, 2, 4 or $6 \mathrm{~h}$ after transfection, the cells were collected and washed with PBS(-). The cells were fixed by treatment with $100 \mu \mathrm{L}$ of $4 \%$ paraformaldehyde and then washed with PBS(-). The cell membranes were permeabilized by treatment with $100 \mu \mathrm{L}$ of Methanol $\left(4^{\circ} \mathrm{C}\right)$. The cells were washed twice with FACS buffer $\left(0.5 \% \mathrm{BSA}, 0.1 \% \mathrm{NaN}_{3}\right.$ in PBS(-)), and phosphorylated eIF2 $\alpha$ was reacted with a primary rabbit-a-eIF2a-P antibody (Rabbit monoclonal [E90] to EIF2S1 (phospho S51), Abcam, ab32157, 100-fold dilution) for $45 \mathrm{~min}$. The cells were washed twice with the FACS buffer, and then stained with secondary antibody (Donkey anti-Rabbit IgG $(\mathrm{H}+\mathrm{L})$ Highly Cross-Adsorbed Secondary Antibody, Alexa Fluor 647, Invitrogen ${ }^{\mathrm{TM}}$, A-31573, 100-fold dilution, ThermoFisher Scientific, Waltham, MA, USA). The cells were washed twice, and the cells were re-fixed with $1 \%$ paraformaldehyde. The fluorescence of the Alexa Fluor 647 was measured by Novocyte ${ }^{\mathrm{TM}}$ flow cytometer (Agilent, Santa Clara, CA, USA).

\subsection{Analysis of Cellular Uptake}

2.7.1. Analysis of the LNPs with Different Composition

LNPs without mRNA were prepared with different amounts of PEG-lipids $(0.375 \%$, $0.75 \%, 1.5 \%$, or $3 \%$ ) or phospholipids (DOPC, POPC, or POPE). The LNPs were labelled with $0.2 \%$ of DiD fluorescent dye. The cells were pre-incubated for $30 \mathrm{~min}$ at $37^{\circ} \mathrm{C}$ or on ice. Jurkat cells were transfected with the LNPs at a concentration of $40 \mathrm{nmol} / \mathrm{mL}$ total lipids (total of ssPalmO-Phe-P4C2, phospholipids, and cholesterol). The cells were incubated for $3 \mathrm{~h}$ at $37^{\circ} \mathrm{C}$ or on ice. After incubation, the cells were collected and washed with $500 \mu \mathrm{L}$ of FACS buffer twice. Fluorescence of the DiD from the cells was measured by the Novocyte ${ }^{\mathrm{TM}}$ flow cytometer (Agilent, Santa Clara, CA, USA).

\subsubsection{Cellular Uptake of the LNPs in the Presence of an Endocytosis Inhibitor}

For the pre-treatment of the cells, the cells were seeded at $1 \times 10^{5}$ cells $/ \mathrm{mL}$ in serumfree RPMI-1640 medium. The cells were incubated with $30 \mu \mathrm{M}$ Pitstop, $20 \mu \mathrm{M}$ Dynole, $100 \mu \mathrm{M}$ Genistein, or $10 \mu \mathrm{M}$ Cytochalasin D for $20 \mathrm{~min}$. After the incubation, the cell suspension was centrifuged $\left(4^{\circ} \mathrm{C}, 500 \times g, 5 \mathrm{~min}\right)$ and $1 \mathrm{~mL}$ of culture medium containing the same concentration of the inhibitors was added to the pelleted cells. Cells were transfected with the DiD-labelled LNPs without mRNA at a concentration of $40 \mathrm{nmol} / \mathrm{mL}$ total lipids (equivalent to the transfection of $0.2 \mu \mathrm{g}$ mRNA) for $1 \mathrm{~h}$. After transfection, the cells were collected and washed with $500 \mu \mathrm{L}$ of the FACS buffer. Fluorescence of the DiD 
from the cells was measured by means of a Novocyte ${ }^{\mathrm{TM}}$ flow cytometer (Agilent, Santa Clara, CA, USA).

\subsection{Hemolysis Assay}

Whole blood of ICR mice was collected from inferior vena cava in the presence of $0.5 \mu \mathrm{L}$ of heparin sodium $(1000 \mathrm{U} / \mathrm{mL}$ ). The ICR mice (male, 6-7 weeks) were purchased from Japan SLC, Inc. (Shizuoka, Japan). The experimental protocols were reviewed and approved by the Chiba University Animal Care Committee in accordance with the "Guide for Care and Use of Laboratory Animals". The ethical approval code issued from the committee was 30-41. Red blood cells were purified by washing the blood $(1 \mathrm{~mL})$ with $9 \mathrm{~mL}$ of PBS. The blood was centrifuged $\left(4^{\circ} \mathrm{C}, 400 \times g, 5 \mathrm{~min}\right)$ and the supernatant was discarded by aspiration. The washing was repeated 5 times so as to completely remove serum proteins. PMBS buffer was prepared by dissolving DL-malic acid by PBS(-). Final concentration of the malic acid was $20 \mathrm{mM}$. The $\mathrm{pH}$ was then adjusted by $\mathrm{NaOH}$ solution. The red blood cells were then incubated with the LNP at $\mathrm{pH}$ from 5.5 to 7.4. The final concentration of the total lipid was $100 \mu \mathrm{M}$. The mixture was incubated at $37^{\circ} \mathrm{C}$ for $30 \mathrm{~min}$. After the incubation, the samples were centrifuged at $500 \times g$ for $5 \mathrm{~min}$. The absorbance of the leaked hemoglobin in supernatant was measured at $545 \mathrm{~nm}$ by plate reader Infinite 200 (Tecan Japan Co., Ltd., Kanagawa, Japan). As a positive control, the red blood cells were lysed by $0.1 \%(w t / v)$ Triton-X100.

\section{Results}

\subsection{Surface of the LNP Affected to the Transfection Efficiency}

As a main component of LNPs, an SS-cleavable and $\mathrm{pH}$-activated lipid-like material (ssPalmO-Phe-P4C2) was used (Figure 1). Tertiary amine moieties and a disulfide bond in the ssPalmO-Phe-P4C2 promote endosomal escape and the cytoplasmic release of the mRNA, respectively [31]. The use of a combination of a disulfide bond and phenyl esters further improved the cytoplasmic release of the IVT-mRNA via an intraparticle hydrolytic reaction [30]. A commercially available luciferase IVT-mRNA (described in 2.1. materials) was used as a reporter gene. The $\mathrm{LNP}_{\text {ssPalm }}$ formulated with the ssPalmO-Phe-P4C2 contained phospholipids, cholesterol, and polyethylene glycol (PEG)-conjugated lipids as helper lipids (Figure 1). It was previously reported that the $\mathrm{LNP}_{\text {ssPalm }}$ with a lipid composition of ssPalmO-Phe-P4C2/dioleoyl-sn-glycero-phosphatidyl choline (DOPC)/cholesterol/DMGPEG2000 $=52.5 / 7.5 / 40 / 3$ could be used to introduce the IVT-mRNA into HeLa cells (human cervical cancer), CT26 cells (mouse colon carcinoma), Hepa-1c1c7 cells (mouse liver carcinoma), and MEF cells (mouse embryonic fibroblast) [30]. However, this composition showed negligible transfection activity against the Jurkat cells. The ssPalm was a highly hydrophobic molecule and could be dispersed in a water phase only with the aid of the other lipids at a neutral $\mathrm{pH}$ [32]. It can, therefore, be concluded that the $\mathrm{LNP}_{\text {ssPalm }}$ was prevented from aggregation by the surface stabilized with phospholipids and DMGPEG2000. Since this surface appears to be a key interface that regulates interactions with cells, the properties of this surface were modified by changing the content of phospholipids and the amount of PEG-lipid used in their preparation. 

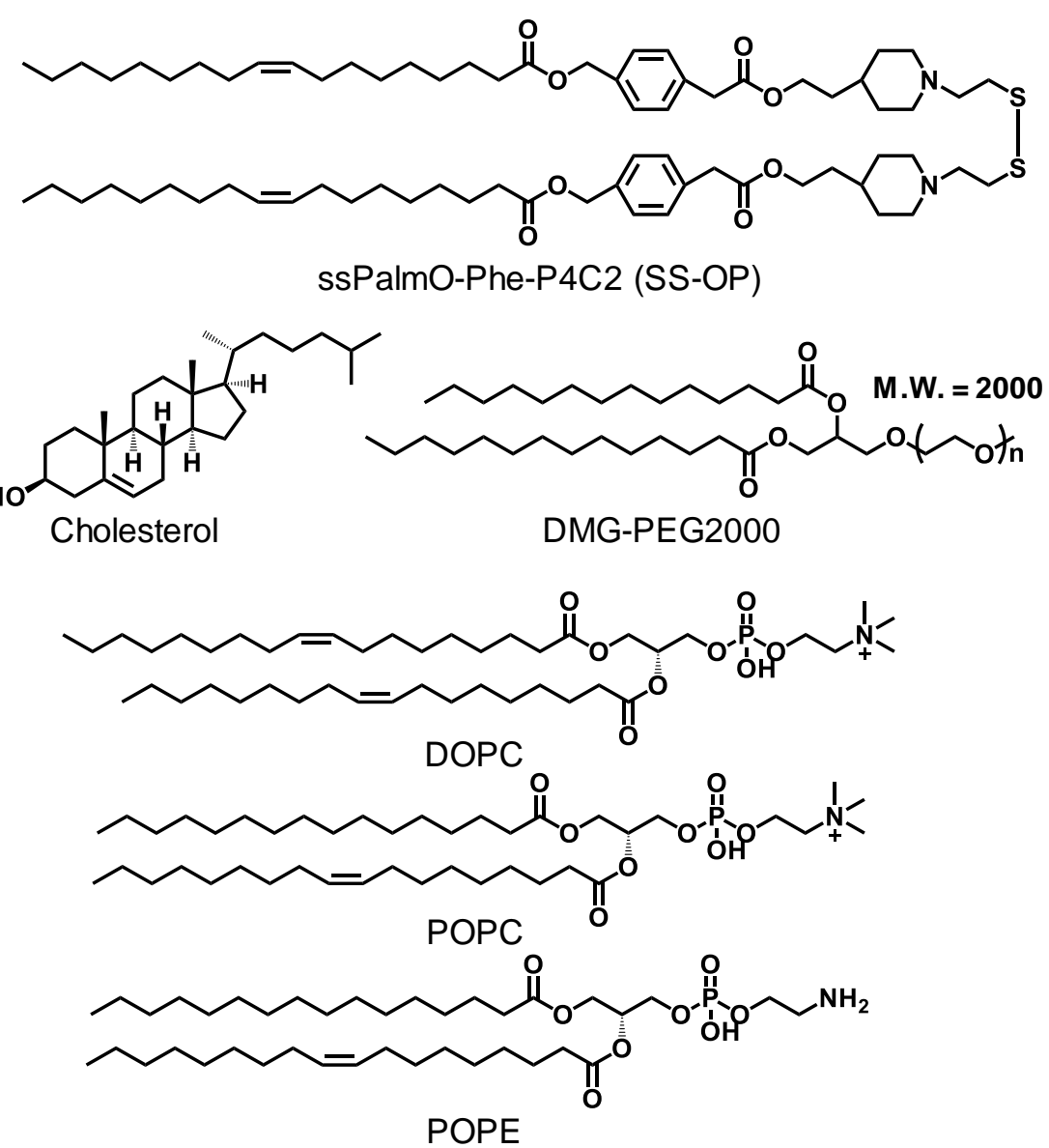

Figure 1. Chemical structures of the lipids used in this study. The chemical structure of the ssPalmOPhe-P4C2, cholesterol, 1-(Monomethoxy polyethylene glycol 2000)2,3-dimyristoylglycerol (DMGPEG2000), 1,2-dioleoyl-sn-glycero-3-phosphatidylcholine (DOPC), 1-palmitoyl-2-oleoyl-sn-glycero3-phosphatidylcholine (POPC), and 1-palmitoyl-2-oleoyl-sn-glycero-3-phosphatidylethanolamine (POPE) were shown.

After a preliminary screening, we found that the use of 1-palmitoyl-2-oleoyl-phosphatidyl ethanolamine (POPE) as a lipid component improved the transfection activity regarding Jurkat cells. An optimized lipid composition of the $\mathrm{LNP}_{\text {ssPalm }}$ was ssPalmO-PheP4C2/POPE/Chol $=50 / 15 / 35$. To evaluate the effects of the surface density of PEG, the amount of the PEG-lipid was changed from 3\% to $0.375 \%$ of the total of other lipids. The properties of the $\mathrm{LNP}_{\text {ssPalm }}$ particles containing luciferase-mRNA are summarized in Table 1. The increase in the PEG resulted in the formulation of a smaller particle, while the changes in Polydispersity index (PdI), Zeta potential, and encapsulation efficiency were marginal. The transfection activity of the $\mathrm{LNP}_{\text {ssPalm }}$ with various densities of DMGPEG2000 and various types of phospholipids was then compared (Figure 2a). As a result, LNPs with POPE showed a higher transfection activity than the LNPs with DOPC regardless of the PEG-lipid content. The most critical finding was that the incorporation of POPE and DMG-PEG2000 at a concentration below 0.75\% showed a high transfection efficiency for the Jurkat cells. Since the chemical structure of POPE and DOPC were different in both hydrophobic scaffolds and hydrophilic heads, it was not possible to identify the important structural unit from this comparison. To clarify the effect of head groups of the phospholipids, the LNPs containing POPE were compared to LNPs containing 1-palmitoyl2-oleyol-phosphatidyl choline (POPC). The comparison indicated that the phosphatidyl ethanolamine group in the POPE is important for the improved transfection efficiency (Figure $2 b$ ). In the following sections the composition of the LNP was fixed to ssPalmO- 
Phe-P4C2 $/$ POPE $/$ Chol/PEG-lipids $=50 / 15 / 35 / 0.75$, since this combination represented the maximum transfection activity.

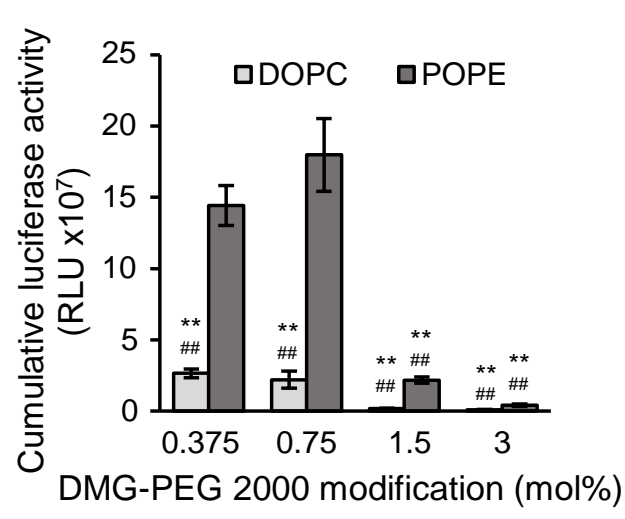

(a)

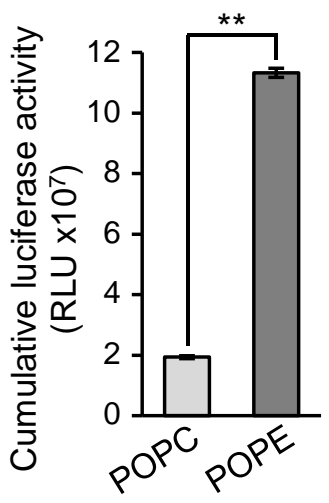

(b)

Figure 2. Transfection activity of the $\mathrm{LNP}_{\mathrm{ssPalm}}$. (a) Effects of phospholipids and PEG-lipids on the mRNA transfection activity. the $\mathrm{LNP}_{\text {ssPalm }}$ with the composition of ssPalmO-Phe-P4C2/DOPC/cholesterol $=52.5 / 7.5 / 40$ or ssPalmO-Phe$\mathrm{P} 4 \mathrm{C} 2 / \mathrm{POPE} /$ cholesterol $=50 / 15 / 30$ were prepared with additional $0.375 \%$ to 3\% of DMG-PEG2000 $(n=3)$. Statistical analyses were performed by the Kruskal-Wallis test followed by Scheffe test, ${ }^{* *} ; p<0.01$ against POPE with $0.375 \%$ PEG, \#\#; $p<0.01$ against POPE with 0.75\% PEG. (b) Effects of the head group of phospholipids on the mRNA transfection activity. The phospholipid content of the $\mathrm{LNP}_{\mathrm{ssPalm}}$ was replaced by the POPC to compare the effects of the head group of phospholipids $(n=3)$. Statistical analysis was performed by the student-t's test, ${ }^{* *} ; p<0.01$.

Table 1. Particle properties of the LNPs in Figure 2.

\begin{tabular}{|c|c|c|c|c|c|}
\hline Helper & PEG Content & Size $(\mathrm{nm})^{1}$ & PdI $^{1}$ & $\begin{array}{c}\text { Zeta } \\
\text { Potential } \\
(\mathrm{mV})^{\mathbf{1}}\end{array}$ & $\begin{array}{c}\text { mRNA } \\
\text { Encapsulation } \\
(\%)^{2}\end{array}$ \\
\hline \multirow[t]{4}{*}{ DOPC } & $0.375 \%$ & $110.4 \pm 8.7$ & $0.15 \pm 0.02$ & $-7.16 \pm 0.59$ & $73.9 \pm 1.6$ \\
\hline & $0.75 \%$ & $66.5 \pm 5.4$ & $0.10 \pm 0.01$ & $-4.47 \pm 0.21$ & $84.0 \pm 1.0$ \\
\hline & $1.5 \%$ & $46.1 \pm 4.7$ & $0.08 \pm 0.03$ & $-3.15 \pm 0.21$ & $85.4 \pm 1.1$ \\
\hline & $3 \%$ & $36.1 \pm 5.1$ & $0.12 \pm 0.06$ & $-2.09 \pm 0.44$ & $84.7 \pm 1.2$ \\
\hline \multirow[t]{4}{*}{ POPE } & $0.375 \%$ & $106.0 \pm 3.6$ & $0.15 \pm 0.00$ & $-8.3 \pm 0.67$ & $79.0 \pm 0.7$ \\
\hline & $0.75 \%$ & $63.2 \pm 4.3$ & $0.12 \pm 0.01$ & $-5.9 \pm 0.49$ & $85.8 \pm 2.1$ \\
\hline & $1.5 \%$ & $45.5 \pm 0.6$ & $0.08 \pm 0.00$ & $-4.7 \pm 0.53$ & $85.6 \pm 2.8$ \\
\hline & $3 \%$ & $38.9 \pm 2.8$ & $0.11 \pm 0.01$ & $-2.7 \pm 0.57$ & $83.9 \pm 1.3$ \\
\hline
\end{tabular}

${ }^{1}$ Size, PdI, and Zeta potential were evaluated by dynamic light scattering. ${ }^{2}$ mRNA encapsulation was evaluated by Ribogreen $^{\mathrm{TM}}$ assay.

\subsection{The LNP ssPalm Enables Comparable Transfection Activity to the Electroporation without Stress}

The transfection efficiency of the $\mathrm{LNP}_{\text {ssPalm }}$ containing POPE was compared to that for electroporation (EP) and the lipofectamine messengerMAX (LFN). The expression of the luciferase mRNA was evaluated by an incubator type luminometer (Figure 3a). The EP showed higher luciferase expression at early times of the transfection. However, the attenuation in the luciferase expression of the EP was faster than that for the LNPs. A comparison of the cumulative luciferase activity revealed that the transfection efficiency of the LNPs was significantly higher than the LFN and was comparable to that for the EP (Figure 3b). The LNP showed no toxicity against Jurkat cells regardless of the IVT-mRNA

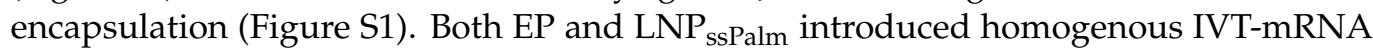
into the Jurkat cells as evaluated by the transfection of EGFP (Figure S2). 


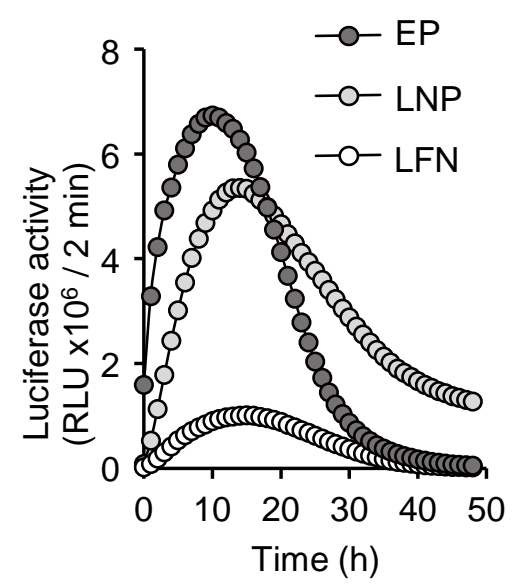

(a)

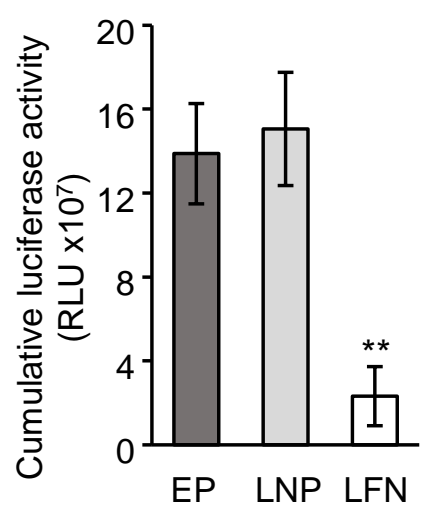

(b)

Figure 3. Transfection efficiency of the $\mathrm{LNP}_{\mathrm{ssPalm}}$ and other transfection methods. (a) Comparison with the general transfection procedures. The transfection activity of the $\mathrm{LNP}_{\text {ssPalm }}$ was compared to the electroporation (EP) or a commercially available lipofection reagent (lipofectamine messengerMAX; LFN). The luminescence from the cultured cells was measured for $2 \mathrm{~min}$ in the incubator-type luminometer. Cumulative light unit for $2 \mathrm{~min}$ was plotted against time, transfected with mRNA. The mean of the independent experiments is shown $(n=3)$. (b) Cumulative luciferase activity. The transfection activity was accumulated for $48 \mathrm{~h}$. Data were represented as mean $\pm \operatorname{SD}(n=3)$. Statistical analysis was performed by One-way ANOVA followed by Tukey-Kramer test, ${ }^{* *} ; p<0.01$ against LFN.

It was previously reported that electroporation induced integrated-stress-responses (ISRs) [15], an adaptive reaction against diverse cellular stresses such as unfolded protein responses, deprivation of nutrients, mitochondrial damages, and viral infections [33]. The induction of the ISRs results in the phosphorylation of an $\alpha$-subunit of eukaryotic translation initiation factor 2 (eIF2 $\alpha$ ). Since the phosphorylation of eIF2 $\alpha$ results in the shutdown of cap-dependent translation, ISRs should be avoided during the delivery of the IVT-mRNA. To evaluate the extent of ISRs, the phosphorylation level of the eIF2 $\alpha$ was compared by flow-cytometry (Figure 4) [34]. Compared to the EP, which caused a significant increase in the phosphorylation of the eIF $2 \alpha$, no elevation was observed for the transfection with the $\mathrm{LNP}_{\text {ssPalm }}$. These observations indicate that the $\mathrm{LNP}_{\text {ssPalm }}$ with a composition of ssPalmO-Phe-P4C2/POPE/Chol/DMG-PEG02000 $=50 / 15 / 35 / 0.75$ is a promising mRNA delivery system and represents an alternative to EP.

\subsection{The Membrane Destabilizing Activity Was Enhanced by the Surface Modification}

For the delivery of nucleic acids into the cytoplasm, the most important biological barrier is the plasma/endosomal membrane [35]. Endosomal escape efficiency could be evaluated by a hemolysis assay. Although the original purpose of the hemolysis assay was to evaluate the toxicity of hemolytic small drugs, hemolysis activity is frequently taken as an index of membrane destabilizing activity in the field of nucleic acid delivery since the anionic membrane of the red blood cells is a good model for the endosomal membrane $[36,37]$. The hemolysis activity of the $\mathrm{LNP}_{\text {ssPalm }}$ containing different amounts of the DMG-PEG2000 was first compared at pH 7.4 (physiological condition), pH 6.5 (early endosome condition), and $\mathrm{pH} 5.5$ (late endosome condition) (Figure S3). The amount of DMG-PEG2000 ranged from $0.75 \%$ to $3 \%$. At pH 5.5, all of the samples showed a high hemolysis activity and no significant differences were detected among the samples. At $\mathrm{pH}$ 6.5 and $\mathrm{pH} 7.4$, the $\mathrm{LNP}_{\text {ssPalm }}$ with a small amount of the DMG-PEG2000 tended to show a higher hemolytic activity but the overall efficiency was poor. Therefore, the difference between 1.5\% DMG-PEG2000 and 0.75\% DMG-PEG2000 was evaluated in a narrower range of $\mathrm{pH}$, i.e., from $\mathrm{pH} 5.5$ to $\mathrm{pH} 6.5$ (Figure 4). Among the tested $\mathrm{pH}$ values, the $\mathrm{LNP}_{\text {ssPalm }}$ with the $0.75 \%$ DMG-PEG2000 showed a slightly, but significantly higher hemolytic activity 
at $\mathrm{pH} 6.3$ and $\mathrm{pH} 6.1$ (Figure 5). Since the hemolysis activity was affected by an apparent pKa of the surface of LNPs, the pKa of the $\mathrm{LNP}_{\mathrm{ssPalm}}$ with $0.75 \%, 1.5 \%$, or $3.0 \%$ of the DMG-PEG2000 was evaluated by means of a 6-(p-Toluidino)-2-naphthalenesulfonic acid (TNS) assay. The TNS is a fluorescent dye that shows strong fluorescence when the dye is inserted to the hydrophobic environment. Since the TNS has an anionic charge, the dye can interact with the surface of an LNP depending on the cationic charge that develops in the acidic environment. The TNS assay showed that the PEG-lipid content had no effect on the

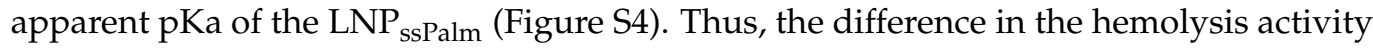
collectively indicated that the decrease in the surface density of PEG-lipid facilitated the physical interaction between LNPs and the biological membrane. To clarify the effect of head groups, the difference between POPC and POPE was evaluated. The comparison also revealed that the $\mathrm{LNP}_{\text {ssPalm }}$ with POPE showed a slightly but significantly higher hemolytic activity at $\mathrm{pH} 6.3$ and $\mathrm{pH} 6.1$ (Figure S5). These data indicate that the $\mathrm{LNP}_{\mathrm{ssPalm}}$ with the composition of ssPalmO-Phe-P4C2/POPE/cholesterol/DMG-PEG = 50/15/35/0.75 enhanced the endosomal escape at an early stage of endocytosis.

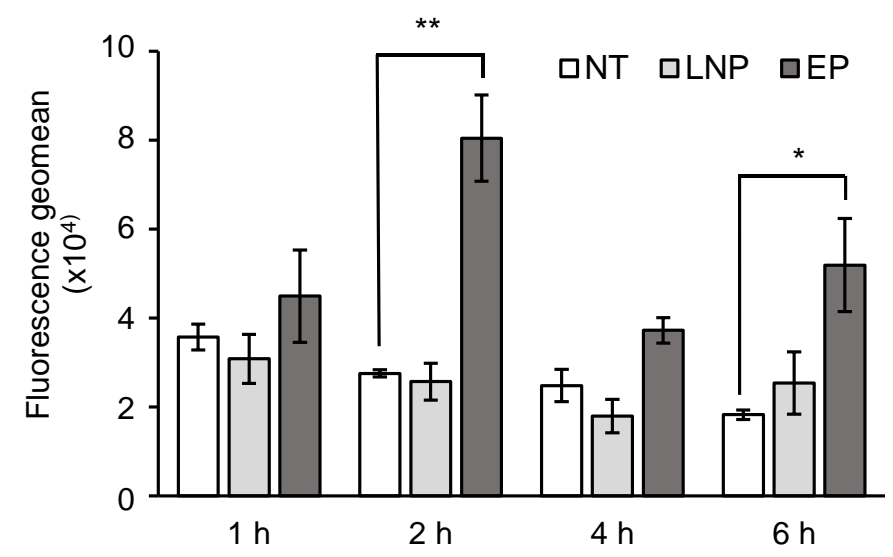

Figure 4. Integrated stress responses induced by the transfection. The phosphorylation level of the eIF2 $\alpha$ was compared. Jurkat cells were fixed and permeabilized after the transfection. The intracellular amount of phosphorylated eIF $2 \alpha$ was evaluated by an anti-phosphorylated eIF $2 \alpha$ antibody. The phosphorylation level of the eIF2 $\alpha$ of $\mathrm{LNP}_{\text {ssPalm }}$ and electroporation (EP) was compared to the non-treated cells (NT). Data were represented as mean $\pm \mathrm{SD}(n=3)$. Statistical analyses were performed by One-way ANOVA followed by Tukey-Kramer test, ${ }^{*} ; p<0.05$ against non-treated group ${ }^{* *} ; p<0.01$ against non-treated group.

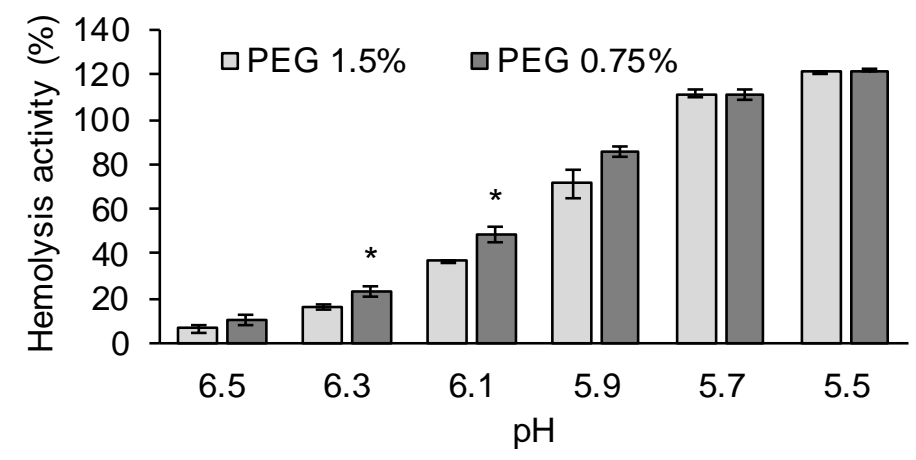

Figure 5. Hemolytic activity of the $\mathrm{LNP}_{\text {ssPalm }}$ with different amount of PEG-lipids. The $\mathrm{LNP}_{\text {ssPalm }}$ with $0.75 \%$ of DMG-PEG2000 or 1.5\% of DMG-PEG2000 was incubated with red blood cells at different $\mathrm{pH}$ from $\mathrm{pH} 5.5$ to $\mathrm{pH}$ 6.5. Data were represented as mean $\pm \mathrm{SD}(n=3)$. Statistical analysis was performed by student-t's test, ${ }^{*} ; p<0.05$. 


\subsection{The LNP $P_{\text {ssPalm }}$ Was Taken Up by the Jurkat Cells via Clathrin/Dynamin-Dependent Endocytosis}

Since the $\mathrm{T}$ cells generally have poor cellular uptake activity, the mechanism responsible for the efficient transfection activity by $\mathrm{LNP}_{\text {ssPalm }}$ is an important information. Since the uptake of the $\mathrm{LNP}_{\text {ssPalm }}$ was almost completely inhibited when the incubation was conducted at $4{ }^{\circ} \mathrm{C}$, the $\mathrm{LNP}_{\text {ssPalm }}$ was assumed to be taken up by the Jurkat cells in an energy-dependent manner. (Figure 6a). The detailed uptake mechanism was evaluated by using pharmacological inhibitors of endocytosis. In this study, Pitstop ${ }^{\circledR} 2$, Dynole ${ }^{\circledR}$ 34-2, Genistein, and Cytochalasin D were used as inhibitors for clathrin-dependent pathway, the dynamin-dependent pathway, the tyrosine kinase-dependent pathway, and the actin-dependent pathway, respectively. In the case of genistein, no decrease in cellular uptake was found. On the other hand, Pitstop and Dynole inhibited cellular uptake by $89 \%$ and $76 \%$, respectively (Figure $6 \mathrm{~b}$ ). These data clearly show that the $\mathrm{LNP}_{\text {ssPalm }}$ was taken up by the Jurkat cells via clathrin/dynamin-dependent endocytosis. While a significant difference was observed in the case of the cytochalasin D treatment, the contribution of the actin molecule was up to $12 \%$ and was much less than that of clathrin and dynamin.

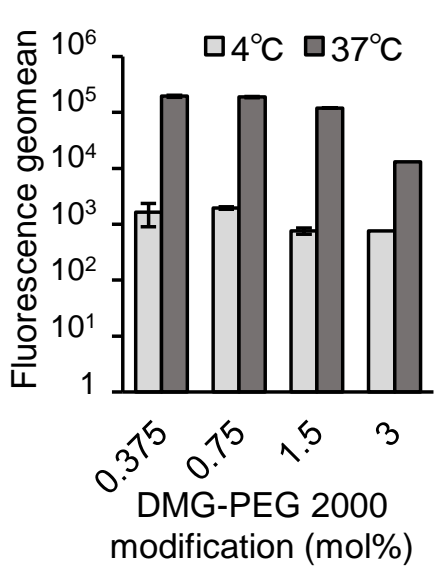

(a)

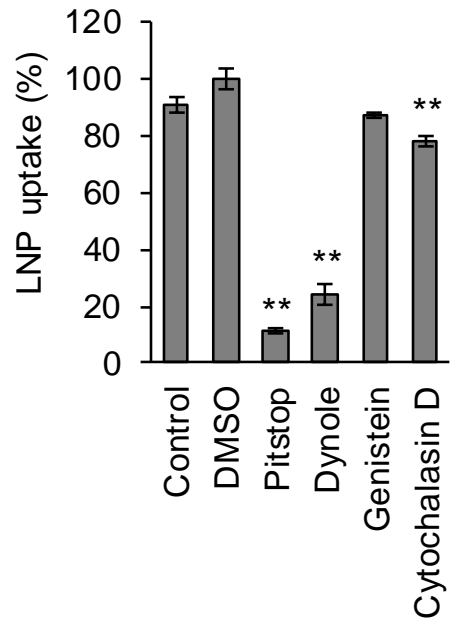

(b)

Figure 6. Uptake mechanism of the $\mathrm{LNP}_{\mathrm{ssPalm}}$. (a) The effects of temperature. The Jurkat cells were incubated with the $\mathrm{LNP}_{\text {ssPalm }}$ at $37^{\circ} \mathrm{C}$ or $4{ }^{\circ} \mathrm{C}$. The cellular uptake was evaluated by flow-cytometry. Data are represented as the mean $\pm \mathrm{SD}(n=3)$. (b) pharmacological inhibition of the endocytosis. The Jurkat cells were incubated with $\mathrm{LNP}_{\mathrm{ssPalm}}$ in the presence of pharmacological inhibitors of endocytosis pathways. As inhibitors, $30 \mu \mathrm{M}$ Pitstop ${ }^{\circledR} 2$ (clathrin inhibitor), $20 \mu \mathrm{M}$ Dynole ${ }^{\circledR} 34-2$ (dynamin inhibitor), $100 \mu \mathrm{M}$ Genistein (tyrosine kinase inhibitor), and $10 \mu \mathrm{M}$ Cytochalasin D (actin inhibitor) were used. Data were represented as mean $\pm \mathrm{SD}(n=3)$. Statistical analyses were performed by Scheffe's F multicomparison test $(n=3),{ }^{* *} ; p<0.01$.

\section{Discussion}

It was reported that the LNPs made with an ionizable lipid, the lipids are distributed in an asymmetric manner; the hydrophobic core of the ionizable lipid was surrounded by the hydrophilic shell made with amphiphilic molecules such as phospholipids and

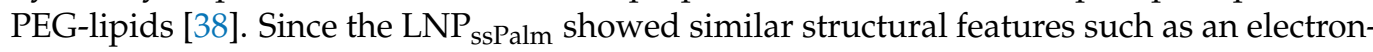
dense spherical structure [30], we hypothesized that the surface of the $\mathrm{LNP}_{\text {ssPalm }}$ was also stabilized by these amphiphilic components in a similar manner. The phospholipid content and the density of the PEG-lipid were modified to investigate the effects of the surface property on the transfection efficiency to Jurkat cells. These modifications resulted in a 221-fold increase in luciferase activity from the LNPs containing DOPC with 3\% DMGPEG2000 compared to LNPs containing POPE with 0.75\% DMG-PEG2000 (Figure 2a). This transfection activity was comparable to that obtained by electroporation. The reduction in the PEG-lipid from 3\% to $0.75 \%$ contributed to a 42.7 -fold increase in transfection activity. A comparison between "DOPC and POPE" (8.14-fold increase, Figure 2a) or 
"POPC and POPE" (5.86-fold increase, Figure 2b) also indicated that the employment of a helper lipid with a phosphoethanolamine structure in the head group is important in terms of maximizing transfection activity. We conclude that the effect of the PEG-lipid was more significant than that of the phospholipids. In the 8.27-fold increase in transfection efficiency that was achieved by changing the PEG-lipid from $1.5 \%$ to $0.75 \%$ (Figure 2a), the cellular uptake of the LNPs accounted for only a 1.8-fold increase (Figure 5a). Thus, the 5.30-fold increase in transfection efficiency can be attributed to intracellular trafficking after endocytosis. Since the PEG on the surface of the $\mathrm{LNP}_{\text {ssPalm }}$ had no effect on responsiveness to $\mathrm{pH}$ (Figure S4), the decrease in the PEG-lipid probably facilitated a physical interaction between the $\mathrm{LNP}_{\text {ssPalm }}$ and the biological membrane, and subsequently enhanced the cytoplasmic delivery of the IVT-mRNA. The decrease in the PEG-lipid also improved transfection activity against Raw264.7 cells (mouse macrophages/monocytes) and HeLa cells (human cervical cancer cells) (Figure S6). It is noteworthy that the effects of the helper lipid on the transfection activity were marginal for these cell lines. Although the overall contribution of changing the helper lipids was smaller than that for the PEG-lipid, the requirement of the phosphatidyl ethanolamine for the transfection to Jurkat cells indicated that the required properties for the nanoparticles for successful transfection to the $\mathrm{T}$ cells are different from these cells with high phagocytosis/micropinocytosis capacities. This observation also indicated that the optimization of the helper lipid content should be performed for the specific target cells being used. During the endocytosis process, receptors on T cells such as TCR, CD4, and CTLA-4 are recycled to the cellular surface via an endocytic recycling compartment. The recycling pathway is also employed to replenish the newly synthesized perforin in cytotoxic $\mathrm{T}$ cells. Thus, the recycling pathway plays a key role in maintaining the function of T cells [39]. The $\mathrm{pH}$ of recycling endosomes decreases to approximately $\mathrm{pH}$ 6.5. Thus, even when LNPs are sorted into the recycling compartment, the escape from this compartment requires membrane destabilizing activity under weakly acidic conditions. Actually, in addition to the poor cellular uptake, the slow rate of the acidification of endosomal compartment was reported to be another biological barrier for the delivery of genes to the T cells by $\mathrm{pH}$ sensitive materials [40]. The enhancement in transfection activity indicated that the incorporation of POPE and the use of $0.75 \%$ DMG-PEG2000 could overcome these barriers. The enhancement in transection efficiency reported here could be explained, at least in part, by the enhanced membrane destabilizing activity of the composition, especially at pH 6.1 and pH 6.3 (Figure 5 and Figure S5), as well as the increased cellular uptake by the decreased level of surface PEG-lipids (Figure 6a). The importance of the endosomal escape at an early stage of endocytosis for the LNP-based mRNA delivery was recently reported as a preprint [41]. In this preprint, it was suggested that endosomal escape which is sufficiently productive to induce protein expression from loaded mRNA occurred mainly from the early endosomal compartment and the recycling compartment, as evidenced by super-resolution microscopy. This observation strongly supports our observations. Since the analysis of intracellular trafficking in the Jurkat cells was difficult because of its low level of cytoplasm and floating nature, evidence of endosomal escape at an early stage of the endocytosis was not clearly shown in this study. However, the hemolysis activity in the $\mathrm{pH}$ 6.1-pH 6.3 region could be used as an index for the further development of LNPs. The limitation of the hemolysis assay was that the contribution of proteins cannot be evaluated. A hemolysis assay in the presence of serum would be a more accurate index for the expected efficiency of LNPs [42].

Based on experiments involving pharmacological inhibitors of endocytosis, the findings revealed that the $\mathrm{LNP}_{\text {ssPalm }}$ particles were internalized into the Jurkat cells via clathrinmediated endocytosis (CME). This CME is a common uptake pathway and plays a key role in nutrient uptake, receptor signaling, and vesicle recycling [43]. In the case of T cells, clathrin-mediated endocytosis would be expected to be the most active pathway [6]. The size of the clathrin-coated pit was reported to be less than $200 \mathrm{~nm}$ [44]. Since the size of the LNP ssPalm $_{\text {was below }} 100 \mathrm{~nm}$, the contribution of this clathrin-mediated pathway is reasonable. Since the transfection activity of the $\mathrm{LNP}_{\text {ssPalm }}$ was also inhibited by the 
inhibitor of CME, the contribution of this pathway to the successful cytoplasmic delivery was confirmed (Figure S7). It was reported that CME is important for the delivery of siRNA [45]. In this report, the down-regulation of the clathrin heavy chain reduced the uptake of the LNP by about half. It was reported that the inhibition of the budding of clathrin-coated particle by the cytosolic acidification and by treatment with chlorpromazine treatment strongly inhibits the cellular uptake of the LNP [46]. It was also suggested that the infection by viral particles requires CME [47]. Taking these reports into account, the internalization of the $\mathrm{LNP}_{\text {ssPalm }}$ via CME might be an important feature for the successful delivery of the cargo into the cell. In general, CME is known to be a receptor-dependent specific mechanism. We thus hypothesize that the $\mathrm{LNP}_{\text {ssPalm }}$ interacted with the surface protein(s) of the T cells, while the specific target and manner of the interaction remains to be clarified. Our experiments indicate that phagocytosis or macropinocytosis, the targets of genistein and cytochalasin $\mathrm{D}$, respectively, are not important as the CME for T cells. This character of the T cells is one of the reasons for the notion that LNPs are poorly taken up by $\mathrm{T}$ cells.

In this study, the level of the phosphorylation of eIF2 $\alpha$ was investigated as an index of ISRs. A schematic illustration and the importance of the ISRs are summarized in Figure S8. The induction of the ISRs in T cells are important in cancer immunotherapy. The expression of a stress related-transcription factor C/EBP homologous protein (CHOP), a consequence of protein kinase RNA-like endoplasmic reticulum kinase (PERK)-dependent and tumor-induced ISRs, results in a decreased cytotoxicity of T cells [48]. Thus, the ISRs in T cells has adverse effects on, not only the extent of protein expression, but also on the efficacy of T cell therapy. In the case of electroporation, the ISRs were induced by general control nonderepressible 2 (GCN2) and PERK [15]. GCN2 is a kinase which senses an increase in the levels of amino acid-uncharged t-RNA. The uncharged $t$-RNA increases in response to the decrease in available nutrients under the conditions such as serum depletion $[49,50]$. PERK is a kinase that senses the unfolded protein in the endoplasmic reticulum [51]. The activation of GCN2 and PERK by electroporation may indicate that the pore formation on these biological membranes results in the leakage of the contents of cytoplasm/endoplasmic reticulum into the extracellular space. This leakage would be expected to result in the disruption in the homeostasis of cells. The non-phosphorylation of eIF2 $\alpha$ in the $\mathrm{LNP}_{\text {ssPalm }}$ incubation indicated that the disturbance of the homeostasis by the $\mathrm{LNP}_{\text {ssPalm }}$ was not significant, since the damage of the biological membrane occurs only in the acidic endosomal compartment in the case of the $\mathrm{LNP}_{\mathrm{ssPalm}}$. Since the $\mathrm{LNP}_{\mathrm{ssPalm}}$ showed no ISRs against Jurkat cells, we conclude that the LNP ssPalm represents a viable alternative to electroporation. However, it is known that a high level of leakage of endosomal contents causes the apoptosis or necrosis [52-54]. Careful investigations of the effects of the LNPs on such cells is still needed.

Recently, the successful induction of the human CAR-T cells by LNP-based mRNA delivery was reported [55]. It was shown that the viability of $T$ cells treated with these LNPs was superior to that treated with electroporation. These observations confirm that LNPs represent a safe alternative to the conventional electroporation method. In that report, LNPs that showed a high transfection activity for Jurkat cells could also introduce mRNA into primary human $\mathrm{T}$ cells. This indicates that Jurkat cells can work as a surrogate for the evaluation of transfection efficiency of a LNP system for T cells. On the other hand, it has been also known that properties such as signal transduction of immortalized $\mathrm{T}$ cells are different from those of activated primary T cells [56]. In addition to this point, our study investigated the efficiency of delivery of mRNA, but the effects of LNPs on the original cell-killing function of $\mathrm{T}$ cells remain to be clarified. For these reasons, the usefulness of the LNP system should be evaluated using primary T cells to make a clear conclusion. Especially, the importance of the uptake via CME and avoidance of ISRs observed in this study should be evaluated by functional evaluation using a primary culture system. 


\section{Conclusions}

In this study, we report on the development of an $\mathrm{LNP}_{\mathrm{ssPalm}}$ with the composition of ssPalmO-Phe-P4C2/POPE/cholesterol/DMG-PEG $=50 / 15 / 35 / 0.75$ for the delivery of IVT-mRNA to Jurkat cells. The particles were taken up by clathrin/dynamin-dependent endocytosis. This composition showed membrane destabilizing activity at a slightly acidic $\mathrm{pH}$ from $\mathrm{pH}$ 6.1-6.3. It was thus hypothesized that hemolytic activity in this $\mathrm{pH}$ range can be used as an index for evaluating the cytoplasmic delivery of mRNA to the T cells. Since the transfection with the $\mathrm{LNP}_{\text {ssPalm }}$ showed no stress responses in the Jurkat cells, it would appear that the $\mathrm{LNP}_{\text {ssPalm }}$ represents a safe alternative technology for introducing proteins into such cells.

\section{Patents}

H. Tanaka, Y. Nakai, K. Tange, H. Yoshioka, and H. Akita are the inventors of the patent pending (WO2019/188867) on the ssPalm chemicals.

Supplementary Materials: The following are available online at https://www.mdpi.com/article/10 .3390/pharmaceutics13122097/s1, Table S1: Detailed list of supplier's information of the reagents, Figure S1: In vitro toxicity evaluation of the $\mathrm{LNP}_{\mathrm{ssPalm}}$, Figure S2: Homogeneous expression of

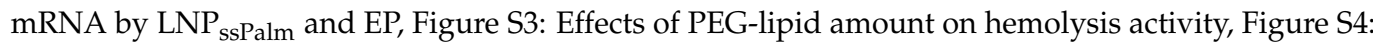
Apparent pKa of the LNPs with different amount of PEG-lipid, Figure S5: Effects of phospholipids on hemolysis activity, Figure S6: Transfection activity against other cell lines, Figure S7: Transfection activity in the presence of the CME inhibitor, Figure S8: Schematic illustration of integrated stress responses (ISRs).

Author Contributions: Conceptualization, H.T. and H.A.; validation, Y.S., S.T., Y.N., K.T. and H.Y.; formal analysis, H.T. and R.M; investigation, R.M., Y.S., S.T., Y.N., K.T., and H.Y.; resources, S.T., Y.N., K.T. and H.Y.; data curation, H.T. and Y.S.; writing-original draft preparation, H.T. and R.M.; writing-review and editing, H.T., R.M., Y.S., Y.N., K.T. and H.A.; visualization, H.T. and R.M.: supervision, H.A.; project administration, H.T., Y.N. and H.A.; funding acquisition, H.T. and H.A. All authors have read and agreed to the published version of the manuscript.

Funding: H. Tanaka was supported by the JSPS KAKENHI (grant numbers 17H06558, 18K18377, 21K18035), Kato Memorial Bioscience Foundation, and The Inohana Foundation (Chiba University). H. Akita was supported by a JST CREST grant (grant number JPMJCR17H1), JSPS KAKENHI (grant numbers 20H00657, 21K18320) and the Asahi Glass Foundation. H. Tanaka and H. Akita were funded by NOF CORPORATION as a joint research.

Institutional Review Board Statement: The study was approved by the Institutional Review Board of Chiba University (protocol code 30-41 (2 January 2019)).

Informed Consent Statement: Not applicable.

Data Availability Statement: The data presented in this study are available on request from the corresponding author.

Acknowledgments: The authors wish to thank M.S. Feather for his helpful advice in writing the English manuscript.

Conflicts of Interest: This research was conducted as a joint research between Chiba University and NOF CORPORATION. The other funders had no role in the design of the study; in the collection, analyses, or interpretation of data; in the writing of the manuscript, or in the decision to publish the results.

\section{References}

1. Laidlaw, B.J; Craft, J.E.; Kaech, S.M. The multifaceted role of CD4(+) T cells in CD8(+) T cell memory. Nat. Rev. Immunol. 2016, 16, 102-111. [CrossRef] [PubMed]

2. Met, Ö.; Jensen, K.M.; Chamberlain, C.A.; Donia, M.; Svane, I.M. Principles of adoptive T cell therapy in cancer. Semin. Immunopathol. 2019, 41, 49-58. [CrossRef] [PubMed]

3. Jackson, H.J.; Rafiq, S.; Brentjens, R.J. Driving CAR T-cells forward. Nat. Rev. Clin. Oncol. 2016, 13, 370-383. [CrossRef] [PubMed]

4. Sermer, D.; Brentjens, R. CAR T-cell therapy: Full speed ahead. Hematol. Oncol. 2019, 37 (Suppl. S1), 95-100. [CrossRef] 
5. Amor, C.; Feucht, J.; Leibold, J.; Ho, Y.J.; Zhu, C.; Alonso-Curbelo, D.; Mansilla-Soto, J.; Boyer, J.A.; Li, X.; Giavridis, T.; et al. Senolytic CAR T cells reverse senescence-associated pathologies. Nature 2020, 583, 127-132. [CrossRef]

6. Wagner, J.; Wickman, E.; DeRenzo, C.; Gottschalk, S. CAR T Cell Therapy for Solid Tumors: Bright Future or Dark Reality? Mol. Ther. 2020, 28, 2320-2339. [CrossRef]

7. Chen, J.; López-Moyado, I.F.; Seo, H.; Lio, C.J.; Hempleman, L.J.; Sekiya, T.; Yoshimura, A.; Scott-Browne, J.P.; Rao, A. NR4A transcription factors limit CAR T cell function in solid tumours. Nature 2019, 567, 530-534. [CrossRef]

8. Zhao, J.; Lin, Q.; Song, Y.; Liu, D. Universal CARs, universal T cells, and universal CAR T cells. J. Hematol. Oncol. 2018, 11, 132. [CrossRef]

9. Dai, X.; Mei, Y.; Cai, D.; Han, W. Standardizing CAR-T therapy: Getting it scaled up. Biotechnol. Adv. 2019, 37, 239-245. [CrossRef]

10. Hacein-Bey-Abina, S.; Von Kalle, C.; Schmidt, M.; McCormack, M.P.; Wulffraat, N.; Leboulch, P.; Lim, A.; Osborne, C.S.; Pawliuk, R.; Morillon, E.; et al. LMO2-associated clonal T cell proliferation in two patients after gene therapy for SCID-X1. Science 2003, 302, 415-419. [CrossRef]

11. Modlich, U.; Schambach, A.; Brugman, M.H.; Wicke, D.C.; Knoess, S.; Li, Z.; Maetzig, T.; Rudolph, C.; Schlegelberger, B.; Baum, C. Leukemia induction after a single retroviral vector insertion in Evi1 or Prdm16. Leukemia 2008, 22, 1519-1528. [CrossRef]

12. Bosticardo, M.; Ghosh, A.; Du, Y.; Jenkins, N.A.; Copeland, N.G.; Candotti, F. Self-inactivating retroviral vector-mediated gene transfer induces oncogene activation and immortalization of primary murine bone marrow cells. Mol. Ther. 2009, 17, 1910-1918. [CrossRef]

13. Dotti, G.; Gottschalk, S.; Savoldo, B.; Brenner, M.K. Design and development of therapies using chimeric antigen receptorexpressing T cells. Immunol. Rev. 2014, 257, 107-126. [CrossRef]

14. Fleischer, L.C.; Spencer, H.T.; Raikar, S.S. Targeting T cell malignancies using CAR-based immunotherapy: Challenges and potential solutions. J. Hematol. Oncol. 2019, 12, 141. [CrossRef]

15. Anderson, B.R.; Kariko, K.; Weissman, D. Nucleofection induces transient eIF2alpha phosphorylation by GCN2 and PERK. Gene Ther. 2013, 20, 136-142. [CrossRef]

16. Fenton, O.S.; Kauffman, K.J.; Kaczmarek, J.C.; McClellan, R.L.; Jhunjhunwala, S.; Tibbitt, M.W.; Zeng, M.D.; Appel, E.A.; Dorkin, J.R.; Mir, F.F.; et al. Synthesis and Biological Evaluation of Ionizable Lipid Materials for the In Vivo Delivery of Messenger RNA to B Lymphocytes. Adv. Mater. 2017, 29, 1606944. [CrossRef]

17. Fenton, O.S.; Kauffman, K.J.; McClellan, R.L.; Appel, E.A.; Dorkin, J.R.; Tibbitt, M.W.; Heartlein, M.W.; DeRosa, F.; Langer, R.; Anderson, D.G. Bioinspired Alkenyl Amino Alcohol Ionizable Lipid Materials for Highly Potent In Vivo mRNA Delivery. Adv. Mater. 2016, 28, 2939-2943. [CrossRef]

18. Jayaraman, M.; Ansell, S.M.; Mui, B.L.; Tam, Y.K.; Chen, J.; Du, X.; Butler, D.; Eltepu, L.; Matsuda, S.; Narayanannair, J.K.; et al. Maximizing the potency of siRNA lipid nanoparticles for hepatic gene silencing in vivo. Angew. Chem. Int. Ed. Engl. 2012, 51, 8529-8533. [CrossRef]

19. Kauffman, K.J.; Dorkin, J.R.; Yang, J.H.; Heartlein, M.W.; DeRosa, F.; Mir, F.F.; Fenton, O.S.; Anderson, D.G. Optimization of Lipid Nanoparticle Formulations for mRNA Delivery in Vivo with Fractional Factorial and Definitive Screening Designs. Nano Lett. 2015, 15, 7300-7306. [CrossRef]

20. Oberli, M.A.; Reichmuth, A.M.; Dorkin, J.R.; Mitchell, M.J.; Fenton, O.S.; Jaklenec, A.; Anderson, D.G.; Langer, R.; Blankschtein, D. Lipid Nanoparticle Assisted mRNA Delivery for Potent Cancer Immunotherapy. Nano Lett. 2017, 17, 1326-1335. [CrossRef]

21. Zimmermann, T.S.; Lee, A.C.; Akinc, A.; Bramlage, B.; Bumcrot, D.; Fedoruk, M.N.; Harborth, J.; Heyes, J.A.; Jeffs, L.B.; John, M.; et al. RNAi-mediated gene silencing in non-human primates. Nature 2006, 441, 111-114. [CrossRef]

22. Adams, D.; Gonzalez-Duarte, A.; O’Riordan, W.D.; Yang, C.C.; Ueda, M.; Kristen, A.V.; Tournev, I.; Schmidt, H.H.; Coelho, T.; Berk, J.L.; et al. Patisiran, an RNAi Therapeutic, for Hereditary Transthyretin Amyloidosis. N. Engl. J. Med. 2018, $379,11-21$. [CrossRef]

23. Verbeke, R.; Lentacker, I.; de Smedt, S.C.; Dewitte, H. The dawn of mRNA vaccines: The COVID-19 case. J. Control. Release 2021, 333, 511-520. [CrossRef]

24. Jackson, L.A.; Anderson, E.J.; Rouphael, N.G.; Roberts, P.C.; Makhene, M.; Coler, R.N.; McCullough, M.P.; Chappell, J.D.; Denison, M.R.; Stevens, L.J.; et al. An mRNA Vaccine against SARS-CoV-2-Preliminary Report. N. Engl. J. Med. 2020, 383, $1920-1931$. [CrossRef]

25. Corbett, K.S.; Edwards, D.K.; Leist, S.R.; Abiona, O.M.; Boyoglu-Barnum, S.; Gillespie, R.A.; Himansu, S.; Schäfer, A.; Ziwawo, C.T.; DiPiazza, A.T.; et al. SARS-CoV-2 mRNA vaccine design enabled by prototype pathogen preparedness. Nature 2020, 586, 567-571. [CrossRef]

26. Harris, E.; Zimmerman, D.; Warga, E.; Bamezai, A.; Elmer, J. Nonviral gene delivery to T cells with Lipofectamine LTX. Biotechnol. Bioeng. 2021, 118, 1693-1706. [CrossRef]

27. Nakamura, T.; Kuroi, M.; Fujiwara, Y.; Warashina, S.; Sato, Y.; Harashima, H. Small-sized, stable lipid nanoparticle for the efficient delivery of siRNA to human immune cell lines. Sci. Rep. 2016, 6, 37849. [CrossRef]

28. Cevaal, P.M.; Ali, A.; Czuba-Wojnilowicz, E.; Symons, J.; Lewin, S.R.; Cortez-Jugo, C.; Caruso, F. In Vivo T Cell-Targeting Nanoparticle Drug Delivery Systems: Considerations for Rational Design. ACS Nano 2021, 15, 3736-3753. [CrossRef]

29. Gordon, S. Phagocytosis: An Immunobiologic Process. Immunity 2016, 44, 463-475. [CrossRef] 
30. Tanaka, H.; Takahashi, T.; Konishi, M.; Takata, N.; Gomi, M.; Shirane, D.; Miyama, R.; Hagiwara, S.; Yamasaki, Y.; Sakurai, Y.; et al. Self-Degradable Lipid-Like Materials Based on "Hydrolysis accelerated by the intra-Particle Enrichment of Reactant (HyPER)" for Messenger RNA Delivery. Adv. Funct. Mater. 2020, 30, 1910575. [CrossRef]

31. Akita, H.; Ishiba, R.; Hatakeyama, H.; Tanaka, H.; Sato, Y.; Tange, K.; Arai, M.; Kubo, K.; Harashima, H. A neutral envelope-type nanoparticle containing $\mathrm{pH}$-responsive and SS-cleavable lipid-like material as a carrier for plasmid DNA. Adv. Healthc. Mater. 2013, 2, 1120-1125. [CrossRef] [PubMed]

32. Tanaka, H.; Oasa, S.; Kinjo, M.; Tange, K.; Nakai, Y.; Harashima, H.; Akita, H. Temperature and pH sensitivity of a stabilized self-nanoemulsion formed using an ionizable lipid-like material via an oil-to-surfactant transition. Colloids Surf. B. Biointerfaces 2017, 151, 95-101. [CrossRef] [PubMed]

33. Pakos-Zebrucka, K.; Koryga, I.; Mnich, K.; Ljujic, M.; Samali, A.; Gorman, A.M. The integrated stress response. EMBO Rep. 2016, 17, 1374-1395. [CrossRef] [PubMed]

34. Rabouw, H.H.; Langereis, M.A.; Anand, A.A.; Visser, L.J.; de Groot, R.J.; Walter, P.; van Kuppeveld, F.J.M. Small molecule ISRIB suppresses the integrated stress response within a defined window of activation. Proc. Natl. Acad. Sci. USA 2019, 116, 2097-2102. [CrossRef]

35. Xu, E.; Saltzman, W.M.; Piotrowski-Daspit, A.S. Escaping the endosome: Assessing cellular trafficking mechanisms of non-viral vehicles. J. Control. Release 2021, 335, 465-480. [CrossRef]

36. Murthy, N.; Robichaud, J.R.; Tirrell, D.A.; Stayton, P.S.; Hoffman, A.S. The design and synthesis of polymers for eukaryotic membrane disruption. J. Control. Release 1999, 61, 137-143. [CrossRef]

37. Kumar, V.; Qin, J.; Jiang, Y.; Duncan, R.G.; Brigham, B.; Fishman, S.; Nair, J.K.; Akinc, A.; Barros, S.A.; Kasperkovitz, P.V. Shielding of Lipid Nanoparticles for siRNA Delivery: Impact on Physicochemical Properties, Cytokine Induction, and Efficacy. Mol. Ther. Nucleic Acids 2014, 3, e210. [CrossRef]

38. Yanez Arteta, M.; Kjellman, T.; Bartesaghi, S.; Wallin, S.; Wu, X.; Kvist, A.J.; Dabkowska, A.; Szekely, N.; Radulescu, A.; Bergenholtz, J.; et al. Successful reprogramming of cellular protein production through mRNA delivered by functionalized lipid nanoparticles. Proc. Natl. Acad. Sci. USA 2018, 115, E3351-E3360. [CrossRef]

39. Lesteberg, K.; Orange, J.; Makedonas, G. Recycling endosomes in human cytotoxic T lymphocytes constitute an auxiliary intracellular trafficking pathway for newly synthesized perforin. Immunol. Res. 2017, 65, 1031-1045. [CrossRef]

40. Olden, B.R.; Cheng, E.; Cheng, Y.; Pun, S.H. Identifying key barriers in cationic polymer gene delivery to human T cells. Biomater. Sci. 2019, 7, 789-797. [CrossRef]

41. Paramasivam, P.; Franke, C.; Stöter, M.; Höijer, A.; Bartesaghi, S.; Sabirsh, A.; Lindfors, L.; Arteta, M.Y.; Dahlén, A.; Bak, A.; et al. Endosomal escape of delivered mRNA from endosomal recycling tubules visualized at the nanoscale. bioRxiv 2021. [CrossRef]

42. Tanaka, H.; Takata, N.; Sakurai, Y.; Yoshida, T.; Inoue, T.; Tamagawa, S.; Nakai, Y.; Tange, K.; Yoshioka, H.; Maeki, M.; et al. Delivery of Oligonucleotides Using a Self-Degradable Lipid-Like Material. Pharmaceutics 2021, 13, 544. [CrossRef]

43. Canton, I.; Battaglia, G. Endocytosis at the nanoscale. Chem. Soc. Rev. 2012, 41, 2718-2739. [CrossRef]

44. McMahon, H.T.; Boucrot, E. Molecular mechanism and physiological functions of clathrin-mediated endocytosis. Nat. Rev. Mol. Cell Biol. 2011, 12, 517-533. [CrossRef]

45. Gilleron, J.; Querbes, W.; Zeigerer, A.; Borodovsky, A.; Marsico, G.; Schubert, U.; Manygoats, K.; Seifert, S.; Andree, C.; Stoter, M.; et al. Image-based analysis of lipid nanoparticle-mediated siRNA delivery, intracellular trafficking and endosomal escape. Nat. Biotechnol. 2013, 31, 638-646. [CrossRef]

46. Lin, P.J.; Tam, Y.Y.; Hafez, I.; Sandhu, A.; Chen, S.; Ciufolini, M.A.; Nabi, I.R.; Cullis, P.R. Influence of cationic lipid composition on uptake and intracellular processing of lipid nanoparticle formulations of siRNA. Nanomed. Nanotechnol. Biol. Med. 2013, 9 , 233-246. [CrossRef]

47. Hathout, R.M.; Abdelhamid, S.G.; Metwally, A.A. Chloroquine and hydroxychloroquine for combating COVID-19: Investigating efficacy and hypothesizing new formulations using Bio/chemoinformatics tools. Inform. Med. Unlocked 2020, $21,100446$. [CrossRef]

48. Cao, Y.; Trillo-Tinoco, J.; Sierra, R.A.; Anadon, C.; Dai, W.; Mohamed, E.; Cen, L.; Costich, T.L.; Magliocco, A.; Marchion, D.; et al. ER stress-induced mediator C/EBP homologous protein thwarts effector $\mathrm{T}$ cell activity in tumors through T-bet repression. Nat. Commun. 2019, 10, 1280. [CrossRef]

49. Castilho, B.A.; Shanmugam, R.; Silva, R.C.; Ramesh, R.; Himme, B.M.; Sattlegger, E. Keeping the eIF2 alpha kinase Gcn2 in check. Biochim. Biophys. Acta 2014, 1843, 1948-1968. [CrossRef]

50. Anda, S.; Zach, R.; Grallert, B. Activation of Gcn2 in response to different stresses. PLoS ONE 2017, 12, e0182143. [CrossRef]

51. Gonen, N.; Sabath, N.; Burge, C.B.; Shalgi, R. Widespread PERK-dependent repression of ER targets in response to ER stress. Sci. Rep. 2019, 9, 4330. [CrossRef]

52. Hayashi, M.A.; Nascimento, F.D.; Kerkis, A.; Oliveira, V.; Oliveira, E.B.; Pereira, A.; Rádis-Baptista, G.; Nader, H.B.; Yamane, T.; Kerkis, I.; et al. Cytotoxic effects of crotamine are mediated through lysosomal membrane permeabilization. Toxicon 2008, 52, 508-517. [CrossRef]

53. Villamil Giraldo, A.M.; Appelqvist, H.; Ederth, T.; Öllinger, K. Lysosomotropic agents: Impact on lysosomal membrane permeabilization and cell death. Biochem. Soc. Trans. 2014, 42, 1460-1464. [CrossRef]

54. Alu, A.; Han, X.; Ma, X.; Wu, M.; Wei, Y.; Wei, X. The role of lysosome in regulated necrosis. Acta Pharm. Sinica. B 2020, 10, 1880-1903. [CrossRef] 
55. Billingsley, M.M.; Singh, N.; Ravikumar, P.; Zhang, R.; June, C.H.; Mitchell, M.J. Ionizable Lipid Nanoparticle-Mediated mRNA Delivery for Human CAR T Cell Engineering. Nano Lett. 2020, 20, 1578-1589. [CrossRef]

56. Bartelt, R.R.; Cruz-Orcutt, N.; Collins, M.; Houtman, J.C. Comparison of T cell receptor-induced proximal signaling and downstream functions in immortalized and primary T cells. PLoS ONE 2009, 4, e5430. [CrossRef] 